\title{
The Mo- and Fe-nitrogenases of the endophyte Kosakonia sp. UYSO10 are necessary for growth promotion of sugarcane
}

\author{
Cecilia Taulé $^{1} \cdot$ Hugo Luizzi $^{1} \cdot$ Martín Beracochea $^{1} \cdot$ Cintia Mareque $^{1} \cdot$ Raúl Platero $^{1} \cdot$ Federico Battistoni $^{1}$ (D)
}

Received: 11 October 2018 / Accepted: 19 March 2019 / Published online: 30 March 2019

(C) Università degli studi di Milano 2019

\begin{abstract}
Aim Sugarcane is a multipurpose crop primarily used to produce sugar, energy and bioethanol. It requires high amounts of Nfertilization for optimal growth, which increases production costs and environmental degradation. The contribution of biological nitrogen fixation to Uruguayan commercial sugarcane cultivars was demonstrated previously, and diazotrophic bacteria that were isolated from the stems were characterized and identified. From this collection, the isolate UYSO10 related to the Kosakonia genus (formerly Enterobacter) was described as a plant growth-promoting endophyte of sugarcane plants.

Purpose To evaluate the effect of the inoculation of wild-type and nitrogenase-deficient strains of Kosakonia sp. UYSO10 on sugarcane growth promotion under non-sterile conditions.

Methods Kosakonia sp. UYSO10 was inoculated onto sugarcane setts for plant growth promotion greenhouse experiments. Single and double mutants resulting to the nitrogenase-encoding genes (nifH, anfH) were constructed, and the phenotypes were evaluated in vitro and in vivo.

Results Kosakonia sp. UYSO10 is able to promote sugarcane growth under non-sterile conditions, that strain UYSO10 harbors two functional nitrogenases and the inactivation of both nitrogenase-encoding genes diminish its capacity of promoting growth on sugarcane.

Conclusion All together, the results obtained showed that the biological nitrogen fixation ability of Kosakonia sp. UYSO10 is required for sugarcane growth promotion.
\end{abstract}

Keywords $\mathrm{BNF} \cdot \mathrm{Nitrogenase}$ mutants $\cdot$ nifH $\cdot$ anfH

Electronic supplementary material The online version of this article (https://doi.org/10.1007/s13213-019-01466-7) contains supplementary material, which is available to authorized users.

Federico Battistoni

fbattistoni@iibce.edu.uy

Cecilia Taulé

ctaule@iibce.edu.uy

Hugo Luizzi

hluizzi@gmail.com

Martín Beracochea

mberacochea@iibce.edu.uy

Cintia Mareque

cmareque@iibce.edu.uy

Raúl Platero

rplatero@iibce.edu.uy

1 Microbial Biochemistry and Genomics Department, Clemente Estable Biological Research Institute, Avenida Italia 3318, 11600 Montevideo, Uruguay

\author{
Abbreviations \\ BNF Biological nitrogen fixation \\ PGP Plant growth promotion \\ PGPB Plant growth-promoting bacteria \\ $\mathrm{Pi}$ Post-inoculation
}

\section{Introduction}

Several plant nutrients, including $\mathrm{N}$ and $\mathrm{P}$, are often scarce in the soil and thus can limit the optimal development of crops (Masclaux-Daubresse et al. 2010; Sinclair and Rufty 2012). Although this can be resolved by chemical fertilization, it is very costly and is often applied in excess, which results in harm to the environment via the leaching of nitrates into the ground water and the surface runoff of phosphorous and nitrates, all of which result in the contamination of drinking water and aquatic ecosystems (Adesemoye and Kloepper 2009). These problems obviate the need for the development of new agricultural 
technologies that seek to attain more sustainable production systems with less loss of nutrients and pollution. One alternative is the use of plant growth-promoting bacteria (PGPB). These can stimulate the growth and enhance the health of several crops in various ways that are classified as direct or indirect mechanisms. Direct plant growth promotion (PGP) mechanisms include the increase of nutrient uptake due to biological nitrogen fixation (BNF) and mineral solubilization $(\mathrm{P}, \mathrm{Fe})$ as well as the production of phytohormones such as auxins and cytokinins. Indirect PGP mechanisms include biocontrol against phytopathogens and the induced systemic resistance (ISR) response (Mei and Flinn 2010; Compant et al. 2010).

In nature, plants and bacteria are naturally closely associated in several ways, including non-beneficial and beneficial interactions. Endophytic bacteria are those that can be detected at a particular moment within the tissues of apparently healthy plants (Hallmann et al. 1997; Schulz and Boyle 2006). They do not normally cause any substantial morphological changes inside the plant, such as those that occur with root nodule symbionts such as rhizobia in legumes, and they do not cause any disease damage symptoms, unlike phytopathogens. In comparison with symbionts and phytopathogens, little is known about the molecular basis of endophyteplant interactions, although strong evidence of the beneficial effects on their hosts has been thoroughly reported (Friesen 2013; Hardoim et al. 2015).

Sugarcane (Saccharum officinarum) is a multipurpose crop used in Uruguay to produce sugar, bioethanol, animal feed, and energy. This crop requires high levels of $\mathrm{N}$-fertilization for its optimal growth in the Uruguayan cropping latitudes (Fogliata 1995). In a previous study, we demonstrated the contribution of BNF to Uruguayan sugarcane cultivars using the ${ }^{15} \mathrm{~N}$ isotope dilution method (Taule et al. 2012). Additionally, a collection of putative endophytes associated with the same sugarcane cultivars was constructed. These were characterized genetically and biochemically, and selected diazotrophic strains were identified and their phylogenetic relationships examined (Taulé et al. 2012). A subset of these isolates was inoculated onto micropropagated sugarcane plants (cv. LCP 85384), and this experiment demonstrated that a group of strains, including the diazotrophic strain Kosakonia sp. UYSO10 (formerly Enterobacter sp.), was able to promote the growth of sugarcane plants under gnotobiotic conditions (Taulé et al. 2016). In addition, microscopy studies of strain UYSO10 allowed us to define it as a sugarcane endophyte (Taulé et al. 2016).

The hypothesis of the present work is that BNF is one of the mechanisms used by Kosakonia sp. UYSO10 to promote sugarcane growth. In particular, the aims were to evaluate the effect of the inoculation of Kosakonia sp. UYSO10 and nitrogenase mutants on sugarcane growth under non-sterile conditions.

\section{Materials and methods}

\section{Plant growth promotion experiments under greenhouse conditions}

Stem seed pieces ("setts") from sugarcane commercial cultivars TUC 7742 and LCP 85384 were first clean with water to remove soil particles and secondly washed with $70 \% \mathrm{EtOH}$ to diminish the bacterial adhered to the surface, cut in order to leave one bud per sett, and sown into pots containing $1.5 \mathrm{~kg}$ of sterile sand/soil (2:1) as substrate. The soil was collected from a northern region of the country in which no fertilization or cropping activity had been reported over the preceding 10 years. The soil profile was as follows: $\mathrm{pH} 6.6$, total $\mathrm{N}$ $0.4 \mathrm{mg} / \mathrm{g}$ organic C $3.4 \mathrm{mg} / \mathrm{g}, 7 \mu \mathrm{gP} / \mathrm{g}, 0.05 \mathrm{meq} \mathrm{K} / 100 \mathrm{~g}$, and $22.0 \mu \mathrm{g} \mathrm{Fe} / \mathrm{g}$. Each stem piece was inoculated with a suspension containing Kosakonia sp. UYSO10 $\left(1 \times 10^{7}\right.$ cells plant $^{-1}$ ) in the base of the stem at 20 and 65 days after sowing. In the positive control treatment, $0.18 \mathrm{~g}$ of urea was added in each pot containing one sett, while in the negative control, plants without $\mathrm{N}$-fertilization remained uninoculated. The experiment included 10 replicates per treatment and was a completely randomized design. The pots were located in a greenhouse with a photoperiod of $16 / 8 \mathrm{~h}$ light/darkness and were watered with tap water as required.

In all the sugarcane PGP experiments, the plant height (measured from the stem base to the newest leaf blade joint) and the diameter of the basal stem were determined 4 months after the first bacterial inoculation. Roots and aerial parts were dried at $65^{\circ} \mathrm{C}$ for dry weight determination. Total $\mathrm{N}$ content of the aerial parts was determined with the Kjeldjhal method at the Animal Nutrition Laboratory of the Faculty of AgronomyUdelaR.

Parametric data were analyzed by ANOVA and means compared by the least significant differences test (LSD) at $p<0.05$ (InfoStat 2008). Non-parametric data were analyzed by Kruskal-Wallis test and the treatment means were compared using the same test at $p<0.05$ (Infostat 2008).

\section{Genomics analysis of nitrogenase encoding operons}

Nitrogenase genes (nif and anf operons) were identified on the genome draft annotation of the strain Kosakonia sp. UYSO10 (Beracochea et al. in preparation). The mentioned operons were compared with their homologs in the strains Gluconacetobacter diazothrophicus Pal5 (GCA_000021325.1), Azotobacter vinelandii DJ (GCA_000021045.1), and Kosakonia radicincitans DSM16656 (GCA 000280495.2). The aforementioned comparison was carried out using BLASTP version 2.6.0+ with an $e$-value of 0.001 for each strain using UYSO10 as the reference. The BLASTP results were processed with Easyfig 2.2.2 (Sullivan et al. 2011). For the phylogenetic study of the nifH and anfH genes, the aminoacidic sequences were 
aligned using Muscle 3.8.31 (Edgar 2004). The phylogenetic reconstructions were generated using maximum likelihood with the Jones-Taylor-Thornton substitution model with 1000 bootstrap replicates with the software MEGA7 (Kumar et al. 2016).

\section{Construction of $\Delta$ nifH, $\Delta a n f H$, and $\Delta$ nifH $\Delta a n f H$ mutants}

Mutant strains $\Delta$ nifH, $\Delta a n f H$, and double mutant $\Delta$ nifH $\Delta a n f H$ were constructed using an adaptation of the method described by Martínez-García and de Lorenzo (2011) (Supplementary material). The primers nifH-TSF1EcoRI, nifH-TS1R, nifH-TS2F, nifH-TS2R-BamHI, anfHTS1F-EcoRI, anfH-TS1R, anfH-TS2F, and anfH-TS2RBamHI (Table 2) were employed to amplify 500 bp fragments of the flanking upstream (TS1) and downstream (TS2) regions of the nifH and anfH genes, respectively. TS1 and TS2 fragments were joined together by SOE-PCR (Horton et al. 1989) employing TS1F and TS2R primers. The resulting $1.0-\mathrm{kb}$ fragments were digested with EcoRI and BamHI (Thermo, USA), ligated into the $\mathrm{pEMG}$ plasmid (containing I-SceI nuclease recognition site) (Martínez-García and de Lorenzo 2011) treated with the same enzymes, and transformed into DH5- $\alpha \lambda$ pir competent cells. The presence of the plasmid in selected Km-resistant colonies was checked by PCR, and the accuracy of the cloned fragments was confirmed by sequencing the entire TS1-TS2 fragment. The resulting pEMG $\Delta$ nifH and $\mathrm{pEMG} \triangle \mathrm{anf} H$ vectors were transferred to UYSO10 strain by triparental conjugation using E. coli DH5- $\alpha$ (pRK2013) as a helper strain (Figurski and Helinski 1979). Cointegration of the recombinogenic plasmids in the chromosome of the resulting $\mathrm{Km}^{\mathrm{r}}$ UYSO10 colonies was corroborated by PCR using appropriate TS1F and TS2R primers. In order to induce the resolution of the cointegrates, the pSW plasmid bearing a 3-methyl-benzoate (3 MB) inducible $I$-sceI nuclease gene was introduced into the cointegrated $\mathrm{Km}^{\mathrm{r}}$ clones by triparental maiting. Transformed clones were grown overnight in a 5 - $\mathrm{mL}$ tube with LB media, $100 \mathrm{mg} \mathrm{mL}^{-1}$ ampicillin, $40 \mathrm{mg} \mathrm{mL}^{-1}$ gentamicin, and $2 \mathrm{mM} 3 \mathrm{MB}$ for the induction of I-SceI nuclease and plated in LB Ap agar plates. Individual colonies were restreaked in $\mathrm{LB}+\mathrm{Ap}$ and $\mathrm{LB}+\mathrm{Ap}+\mathrm{Km}$ to verify the resolution of the cointegrated constructs. The Kmsensitive clones were analyzed by colony PCR to identify the deletions of nifH or $a n f H$.

For the construction of the double mutant $\Delta$ nifH $\Delta a n f H$, the same protocol for the construction of the $\Delta a n f H$ strain was used but starting with the $\Delta$ nifH strain. Finally, the pSW plasmid was eliminated after three consecutive passes in liquid LB without antibiotic pressure. Curing of the plasmid was verified in all cases by direct colony PCR amplification, using the diagnostic primer pair pSW-F and pSW-R (Table 2).

The complementation plasmids pnifHkosa and panfHkosa (Table 1) were constructed by cloning the nifH and anfH genes in the broad host range vectors pSEVA232 and pSEVA632, respectively (Silva-Rocha et al. 2013). Primers nifH-F-EcoRI/ nifH-R-BamHI and anfH-F-KpnI/anfH-R-BamHI were used for the amplification of the entire iffH and anfH genes from UYSO10 strain. The obtained fragments were digested with indicated enzymes, ligated to the pSEVA232 $\left(\mathrm{Km}^{\mathrm{r}}\right)$ and pSEVA632 $\left(\mathrm{Gm}^{\mathrm{r}}\right)$ vectors digested with appropriated enzymes and transformed into DH5- $\alpha$ competent cells. Blue/ white selection was carried out in LB plates with X-gal 40ugmL $\mathrm{um}^{-1}$ and IPTG $0,1 \mathrm{mM}$ and appropriated antibiotics. Individual white colonies were transferred to fresh LB plates and screened for the presence of the gene insert by PCR. Accuracy of the cloned genes was corroborated by sequencing the entire inserted fragments using the primers PS1 (Table 2) and M13R (universal primer). Plasmids were mobilized from $E$. coli to UYSO10 by triparental mating using $E$. coli $\mathrm{DH} 5-\alpha$ (pRK2013) as a helper strain (Figurski and Helinski 1979).

\section{Characterization of UYSO10 $\Delta$ nifH, $\triangle a n f H$, and $\Delta$ nifHAanfH mutant strains}

The growth of all the strains (wt and mutants) was investigated in LB broth with the aim to determine if the mutations affected the growth under non-BNF conditions. For that, the $\mathrm{OD}_{620 \mathrm{~nm}}$ of the strains were measured by an automated spectrophotometer Varioskan Flash (ThermoScientific), every $2 \mathrm{~h}$ during $6 \mathrm{~h}$.

The ability to fix $\mathrm{N}_{2}$ was tested for every strain by the evaluation of the nitrogenase activity using the acetylene reduction assay (ARA) (Hardy et al. 1968). In order to do so, bacteria were inoculated into vials containing NFCC liquid media (Mirza and Rodrigues 2012), for 4 days at $30^{\circ} \mathrm{C}$, with and without of Mo $9.1 \mu \mathrm{M}$. After that, $10 \%$ of the gas volume was replaced by acetylene, incubated for 3 days at $30^{\circ} \mathrm{C}$ and analyzed for ethylene production by gas chromatography (GC-2010 Plus+, Shimazu), with a column TG-Bond $(30 \mathrm{~m} \times 0.32 \mathrm{~mm} \mathrm{ID} \times 10 \mu \mathrm{m})$ (Thermo Scientific). All the treatments were tested in quintupled, while un-inoculated vials were used as negative control.

\section{Effects of nitrogenase mutations on the sugarcane plant growth promotion}

Micropropagated plantlets of cv. LCP 85384 were inoculated with $1 \times 10^{7}$ cells plant ${ }^{-1}$ of each strain to be tested as previously described (Taulé et al. 2016). Strains tested as inoculants were the wild-type UYSO10, the simple mutants ( $\Delta$ nifH and $\Delta a n f)$; the double mutant $(\Delta n i f H \Delta a n f H)$; as well as the respective complementant strains $(\Delta$ nifH $\Delta$ anfH pnifHkosa and $\Delta$ nifH $\Delta$ anfH panfHkosa).

The experiment setup was randomized with 10 replicates per treatment. Plants were maintained at a temperature of $30{ }^{\circ} \mathrm{C}$ with a photoperiod of $16 / 8 \mathrm{~h}$ light/dark. At $25 \mathrm{dpi}$, plants were transferred to pots containing $1.5 \mathrm{~kg}$ of soil/ 
Table 1 Strains and plasmids used in this study

\begin{tabular}{|c|c|c|}
\hline Name & Feature & Reference \\
\hline $\begin{array}{l}\text { Kosakonia sp. } \\
\text { UYSO10 }\end{array}$ & Wild-type strain & (Taulé et al. 2012) \\
\hline E. coli $\mathrm{DH} 5 \alpha$ & $\begin{array}{l}\text { supE44 } \Delta \text { lacU169( } \$ 80 \text { lacZ } \Delta \text { M15) hsdR17 } \\
\text { recA1 gyrA96 thi-1 relA1 }\end{array}$ & (Hanahan 1983) \\
\hline $\begin{array}{l}\text { E. coli } \mathrm{DH} 5 \alpha \\
\lambda \text { pir }\end{array}$ & $\lambda$ pir lysogen of DH5 $\alpha$ & $\begin{array}{l}\text { (Martínez-García and de } \\
\text { Lorenzo 2011) }\end{array}$ \\
\hline pEMG & Ori6K, $\mathrm{Km}^{\mathrm{r}}$, mob, LacZ $\alpha$ & $\begin{array}{l}\text { (Martínez-García and de } \\
\text { Lorenzo 2011) }\end{array}$ \\
\hline $\mathrm{pEMG} \Delta \mathrm{nifH}$ & $\begin{array}{l}\text { Derivates from pEMG. Non-replicable in Kosakonia. } \\
\text { Recombinogenic. Contains } 500 \text { bp region of } \\
\text { homologies flanking nifH gene }\end{array}$ & This work \\
\hline $\mathrm{pEMG} \Delta \mathrm{anfH}$ & $\begin{array}{l}\text { Derivates from pEMG. Non-replicable in Kosakonia. } \\
\text { Recombinogenic. Contains } 500 \text { bp region of } \\
\text { homologies flanking anfH gene }\end{array}$ & This work \\
\hline pSEVA232 & pBBR1, $\mathrm{Km}^{\mathrm{r}}$, mob. pUC19/LacZ & (Silva-Rocha et al. 2013) \\
\hline pnifHkosa & pSEVA232 with nifH gene cloned in EcoRI/BamHI & This work \\
\hline pSW-2 & $\begin{array}{l}\mathrm{Gm}^{\mathrm{R}} \text {, oriRK2, xylS, Pm } \rightarrow \text { I-sceI (transcriptional } \\
\quad \text { fusion of I-sceI to } \mathrm{Pm} \text { ) }\end{array}$ & $\begin{array}{l}\text { (Martínez-García and de } \\
\text { Lorenzo 2011) }\end{array}$ \\
\hline pSEVA632 & pBBR1, Gmr, mob. pUC19/LacZ & (Silva-Rocha et al. 2013) \\
\hline panfHkosa & pSEVA632 with anfH cloned in KpnI/BamHI & This work \\
\hline
\end{tabular}

sterile sand (2:1) as substrate and maintained in the growth chamber. The soil was collected from the same region as previously mentioned. The height and diameter of the stems, as the plant dry weight, were determined after 4 months pi.

\section{Results}

\section{Plant growth promotion of commercial sugarcane cultivars by Kosakonia sp. UYSO10}

Greenhouse experiments were conducted to determine if the commercial sugarcane cultivars LCP 85384 and TUC 7742 respond equally to inoculation with the diazotrophic strain Kosakonia sp. UYSO10. The results showed that only cultivar LCP 85384 responds to the bacterial inoculation. In this case, the inoculated treatment resulted in a significantly higher stem (height and diameter) and root dry weight in comparison with the un-inoculated control (negative control). When the shoot dry weight was measured, the bacterial inoculation treatment was not significantly different from the negative control but showed significantly higher $\mathrm{N}$ accumulation than the negative control (Table 3).

\section{Nitrogenase mutation effects on the growth and the $\mathrm{N}_{2}$-fixation ability of Kosakonia sp. UYS010}

The bioinformatic analysis showed that genome of the strain Kosakonia sp. UYSO10 contains two types of nitrogenases, the classical FeMo-nitrogenase (encoded by the nif regulon) and the alternative Fe-nitrogenase (encoded by the anf regulon) (Fig. 1). The gene composition and organization of the Kosakonia sp. UYSO10 nif regulon were compared to (1) the closely related strain $K$. radicincitans DSM16656 and (2) the model sugarcane endophyte $G$. diazotrophicus PA15 (Fig. 1, Table S1 Supplementary material). The comparison to strain DSM16656 revealed that the nif regulon gene composition is almost identical to that of strain UYSO10. In particular, the nifH gene shared $100 \%$ amino acid (aa) identity between the strains, while the aa identity ranged from 99.2 to $99.8 \%$ for the other genes of the regulon (Fig. 1; Table S1 Supplementary material). In the second case, the nif structural genes nifHDK are arranged in a cluster on both strains with a low percentage of aa identity. In addition, the nifL gene is missing in the $G$. diazotrophicus PA15 genome (Bertalan et al. 2009).

Alternatively, the gene composition and organization of the Kosakonia sp. UYSO10 anf operon were compared to that of strain DSM16656 and the model organism A. vinelandii DJ. In the first case, the strain UYSO10 anf regulon has $100 \%$ aa identity with that of strain DSM16656 (Fig. 1; Table S1). In the second case, the strain UYSO10 anf regulon shares the cluster anfHDGK, responsible for the nitrogenase synthesis on A. vinelandii DJ, with a low percentage of aa identity (Fig. 1; Table S1).

To elucidate the role of both nitrogenases on the plant growth promotion effects of the sugarcane plants previously described, mutants for the structural nifH and anfH genes were constructed (Supplementary material). The phenotypes of the single $(\Delta n i f H, \Delta a n f H)$ and double $(\Delta n i f H \Delta a n f H)$ mutants 
Table 2 Primers used in this work

\begin{tabular}{lll}
\hline & Primer sequence (5'-3') & Reference \\
\hline nifH-TSF1-EcoRI & Cgaattcctccattaaacgcaccggctg & This work \\
nifH-TS1R & cttcctgttggcgggcgtgcatcggtgttctcetgttggttgtgtg & This work \\
nifH-TS2F & Gatgcacgccegccaacaggaag & This work \\
nifH-TS2R-BamHI & cgggatccgatcccttggtcagcgggaacag & This work \\
anfH-TS1F-EcoRI & Gegaattcgtttgccatcccgcaagggg & This work \\
anfH-TS1R & gactgtaaaataaccggacgaagatatttcctcttgatgaacaac & This work \\
anfH-TS2F & Ttcgtccggttattttacagtc & This work \\
anfH-TS2R-BamHI & Cgggatccctgcgcaatggcggcaatatc & This work \\
pnifH-F-EcoRI & Gcgaattccctgtgccagctcatttatcc & This work \\
pnifH-R-BamHI & cgggatccgcagagcggcgaccaggttttg & This work \\
nifH-R-BamHI & Cgggatcctcaaaccgcgtttcttctgcg & This work \\
panfH-F-KpnI & Ggggtaccctgaatttcacttccgcgaacg & This work \\
panfH-R-BamHI & cgggatcccggatcgcagccatgaataaacac & This work \\
anfH-R-BamHI & cgggatccttaatcgctcagaccatatttaacg & This work \\
pSW-F & ggacgcttcgctgaaaacta & (Martínez-García and de Lorenzo \\
pSW-R & & 2011) \\
PS1 & Aacgtcgtgactgggaaaac & (Martínez-García and de Lorenzo \\
\hline & & 2011) \\
\hline
\end{tabular}

and the complements ( $\Delta$ nifH pnifHkosa, $\Delta$ anfH panfHkosa, $\Delta$ nifH $\Delta$ anfH pnifHkosa, and $\Delta n i f H \Delta$ anfH panfHkosa) were studied in vitro and in vivo.

For the in vitro studies, wild-type and nitrogenase mutant strains were tested for their ability to grow in LB medium (non BNF conditions) (Fig. 2). The results showed that under nonBNF conditions, all the strains have the same growth behavior; thus, the fitness is not affected by the mutation.

In addition, and with the aim of testing the nitrogenase activity, every strain was inoculated into vials containing liquid NFCC media without N, and an ARA assay was conducted. Under these conditions, only the double mutant ( $\Delta$ nifH $\Delta a n f H$ ) was unable to fix nitrogen (Table 4). In addition, results showed that the absence of BNF in the double mutant was overcome when this mutant was complemented in trans with a plasmid encoding the nifH or anfH genes with their respective promoters (Table 4).

\section{Nitrogenase mutations effects on the plant growth promotion of sugarcane plants}

The in vivo characterization of the nitrogenase mutants was evaluated by studying the inoculation effects of the wild-type and mutant strains on micropropagated sugarcane plants $\mathrm{cv}$. LCP 85384 under growth chamber conditions (Fig. 3). In this case, the substrate used was a mixture of sterile sand and soil from the Bella Union region (Uruguay) with a sugarcane crop history without the addition of N-chemical fertilization.

A statistical analysis of the biometric parameters evaluated showed that the inoculation with the simple mutants $(\Delta$ nifH or
Table 3 Effects of inoculation with Kosakonia sp. UYSO10 on sugarcane setts from cv. LCP 85384 , in pots at greenhouse condition (4 months pi)

\begin{tabular}{|c|c|c|c|c|c|c|}
\hline \multirow[t]{2}{*}{ Treatment } & \multirow{2}{*}{$\begin{array}{l}\text { Stem } \\
\text { height } \\
(\mathrm{cm})\end{array}$} & \multirow{2}{*}{$\begin{array}{l}\text { Stem } \\
\text { diameter } \\
(\mathrm{mm})\end{array}$} & \multicolumn{2}{|c|}{$\begin{array}{l}\text { Dry weight } \\
\left(\mathrm{g} \mathrm{plant}^{-1}\right)\end{array}$} & \multirow[t]{2}{*}{$\begin{array}{l}\mathrm{N} \text { concentration (mg } \mathrm{N} \\
\mathrm{g}^{-1} \text { dry weight) }\end{array}$} & \multirow[t]{2}{*}{$\begin{array}{l}\mathrm{N} \text { accumulation } \\
\left(\mathrm{mg} \mathrm{plant}^{-1}\right)\end{array}$} \\
\hline & & & Roots & Shoot & & \\
\hline $\begin{array}{l}\text { Negative } \\
\text { control }\end{array}$ & $13.7 \mathrm{a}^{\mathrm{b}}$ & $6.97 \mathrm{a}$ & $\begin{array}{c}0.83 \\
\mathrm{a}\end{array}$ & $\begin{array}{c}1.79 \\
\mathrm{a}\end{array}$ & $5.90 \mathrm{a}$ & $10.57 \mathrm{a}$ \\
\hline $\begin{array}{l}\text { Kosakonia sp. } \\
\text { UYSO10 }\end{array}$ & $16.00 \mathrm{~b}$ & $7.72 b$ & $\begin{array}{c}1.78 \\
\mathrm{~b}\end{array}$ & $\begin{array}{c}2.36 \\
\mathrm{a}\end{array}$ & $6.06 \mathrm{a}$ & $14.30 \mathrm{~b}$ \\
\hline $\begin{array}{l}\text { Positive } \\
\text { control }\end{array}$ & $22.20 \mathrm{c}$ & $9.06 \mathrm{c}$ & $\begin{array}{c}1.95 \\
\mathrm{~b}\end{array}$ & $\begin{array}{c}4.56 \\
b\end{array}$ & $7.06 \mathrm{~b}$ & $32.17 \mathrm{c}$ \\
\hline
\end{tabular}

${ }^{\text {a }}$ Negative controls: plants uninoculated and without $\mathrm{N}$-fertilization, while positive controls are plant supplemented with urea (equivalent to $100 \mathrm{~kg} \mathrm{~N}^{-1}$ )

${ }^{\mathrm{b}}$ Means within two treatments that have the same letter are not significantly different at $p<0.05$ 

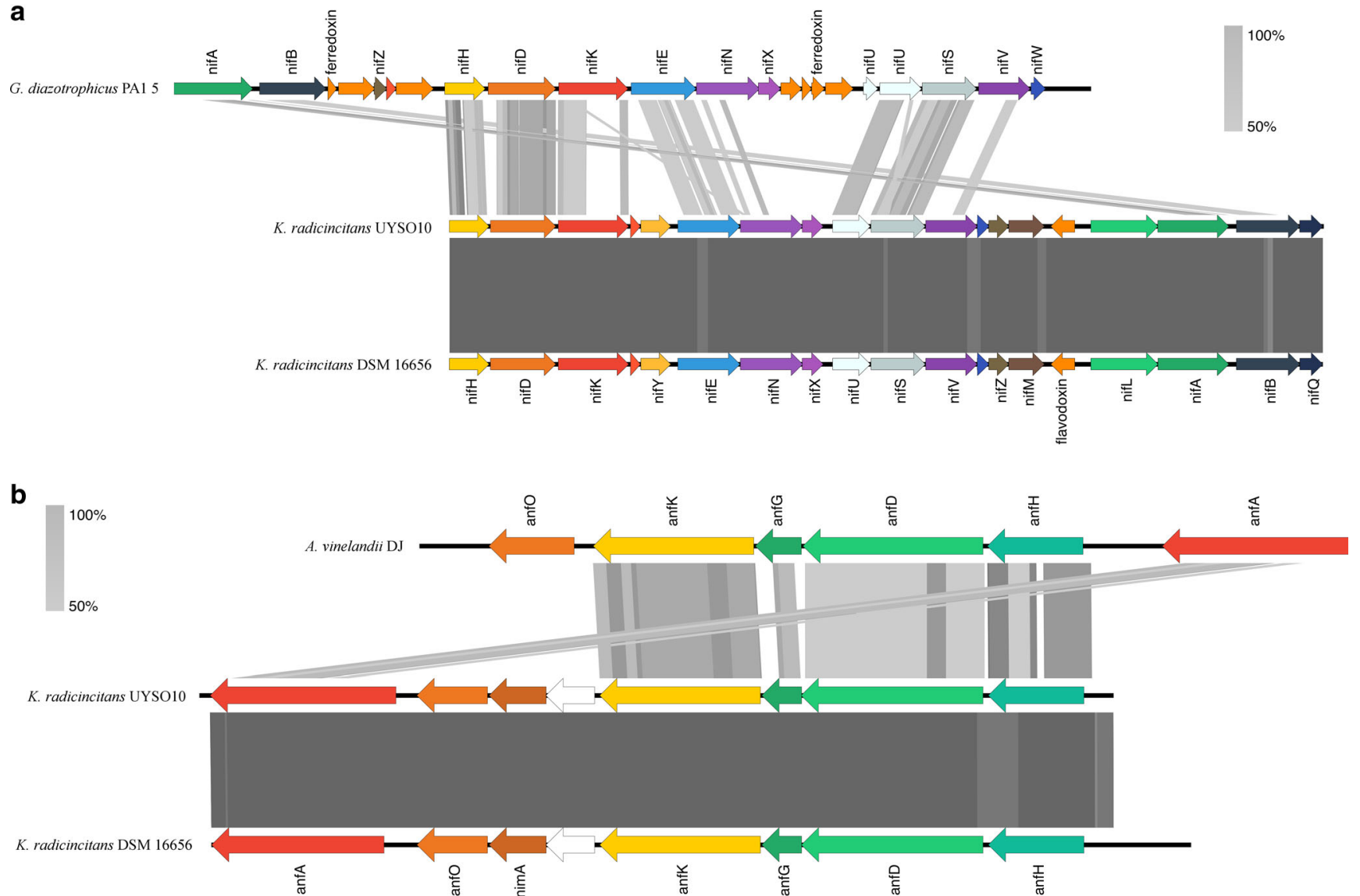

Fig. 1 A schematic comparison of nitrogenase-encoding nif and anf operons in different plant-associated bacteria. a nif operon comparison between the strains Kosakonia sp. UYSO10, Kosakonia radicincitans
DSM16656 ${ }^{\mathrm{T}}$, and Gluconacetobacter diazotrophicus PA1 5; b anf operon comparison between the strains Kosakonia sp. UYSO10, Kosakonia radicincitans DSM16656 ${ }^{\mathrm{T}}$, and Acetobacter vinelandii DJ
$\Delta a n f H)$ was not significantly different than that of the wild type. Nevertheless, when the double mutant $(\Delta$ nifH $\Delta$ anf $H)$ was inoculated, the height, stem diameter, and the aerial dry weight were significantly lower $(9,13$, and $32 \%$, respectively) than the wild-type treatment. In addition, the inoculation with the double mutant strain complemented with a plasmid encoding each mutated gene controlled by its own promoters (strains $\Delta$ nifH $\Delta$ anfH pnifHkosa and $\Delta$ nifH $\Delta$ anfH panfHkosa) recovered the wild-type plant growth promotion effects (Fig. 3).

\section{Discussion}

\section{The plant growth promotion effect depends on plant-bacterial specificity}

Many diazotrophic bacteria have been isolated from different sugarcane cultivars grown in several regions of the world (James 2000; Thaweenut et al. 2011; Fischer et al. 2012; Beneduzi et al. 2013). In addition, the PGP effects on sugarcane from associated or endophytic bacteria, such as $G$. diazotrophicus, Herbaspirillum seropedicae, H. rubrisubalbicans, Azospirillum amazonense, and

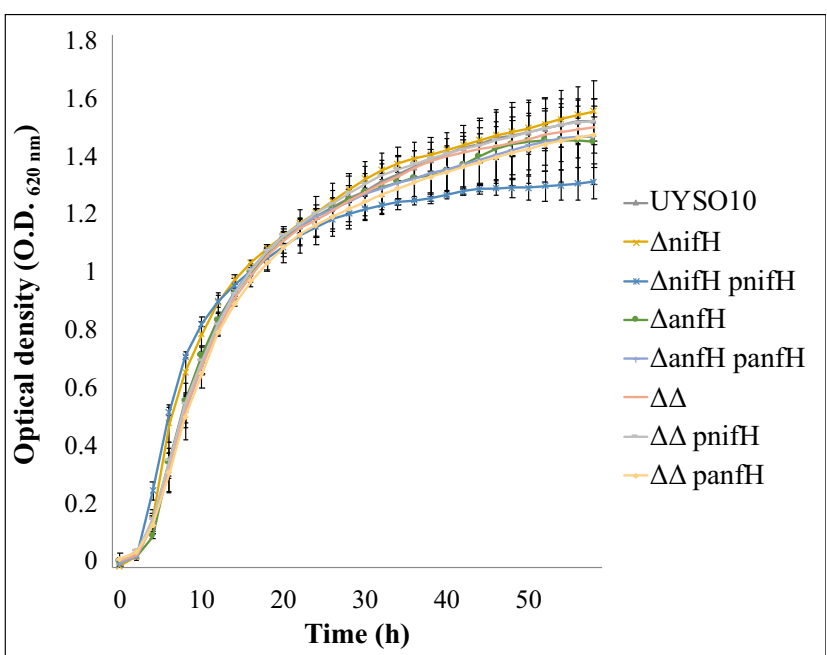

Fig. 2 Growth capacity of Kosakonia sp. UYSO10 wild-type and nitrogenase mutant strains, in 96-well microtiter plate containing LB growth media (non-BNF conditions) 
Table 4 Acetylene reduction activity (ARA) of strains Kosakonia sp. UYSO10 and nitrogenase mutants

\begin{tabular}{|c|c|c|}
\hline & \multicolumn{2}{|l|}{ Culture media } \\
\hline & $\mathrm{NFCC}+\mathrm{Mo} 9.1 \mu \mathrm{M}$ & NFCC-Mo \\
\hline Strain & \multicolumn{2}{|c|}{ Ethylene production } \\
\hline UYSO10 & + & + \\
\hline$\Delta n i f H$ & + & + \\
\hline$\Delta$ nifH pnifHkosa & + & + \\
\hline$\Delta \mathrm{a} n f H$ & + & + \\
\hline$\Delta$ anfH panfHkosa & + & + \\
\hline$\Delta n i f H \Delta \mathrm{a} n f H$ & - & - \\
\hline$\Delta n i f H \Delta$ anfH pnifHkosa & + & + \\
\hline$\Delta$ nifH $\Delta$ anfH panfHkosa & + & + \\
\hline
\end{tabular}

NFCC nitrogen-free combined carbon medium (Mirza and Rodrigues 2012)

Burkholderia spp., have been thoroughly studied (Sevilla et al. 2001; Oliveira et al. 2002, 2006; da Silva et al. 2012).

In a previous study, a collection of putatively endophytic diazotrophic bacteria associated with commercial Uruguayan sugarcane cultivars was constructed, and this was phenotypically and genotypically characterized (Taulé et al. 2012). In addition, a set of these isolates were tested as inoculants in PGP assays on micropropagated sugarcane cv. LCP 85384 under gnotobiotic conditions, and as a result, the strain Kosakonia sp. UYSO10 was determined to be one of the best plant promoters (Taulé et al. 2016). In this study, the inoculation of strain UYSO10 into setts of the two principal commercial sugarcane cultivars planted in Uruguay (LCP 85384 and TUC 7742), under greenhouse conditions, showed plant growth promotion ability only for the $\mathrm{cv}$. LCP 85384 . These results clearly showed a specificity of the plant response to the inoculation conforming to several reports that note that the PGP effects are dependent on the biotic and abiotic conditions as well as the specificity and compatibility of the plant and bacterial genotypes (Reis Junior et al. 2000; Oliveira et al. 2006; Govindarajan et al. 2008; Carvalho et al. 2011). In addition, the inoculation of sugarcane setts with the strain UYSO10 increases the $\mathrm{N}$ accumulation by $35 \%$ compared to the negative control in the cv. LCP 85384 , as previously observed in micropropagated sugarcane plants (Taulé et al. 2016). As described, this cultivar can obtain a significant amount of its N needs via the BNF (Taulé et al. 2012). Several strains from the genus Kosakonia have been described to be plant-associated PGPB (Kämpfer et al. 2005; Witzel et al. 2012; Brock et al. 2013; Bergottini et al. 2015), and the PGP mechanism involved was the BNF in some cases (Zhu et al. 2012; Madhaiyan et al. 2013). The combination of these results led us to evaluate the role of the BNF in the plant-growth promotion observed.
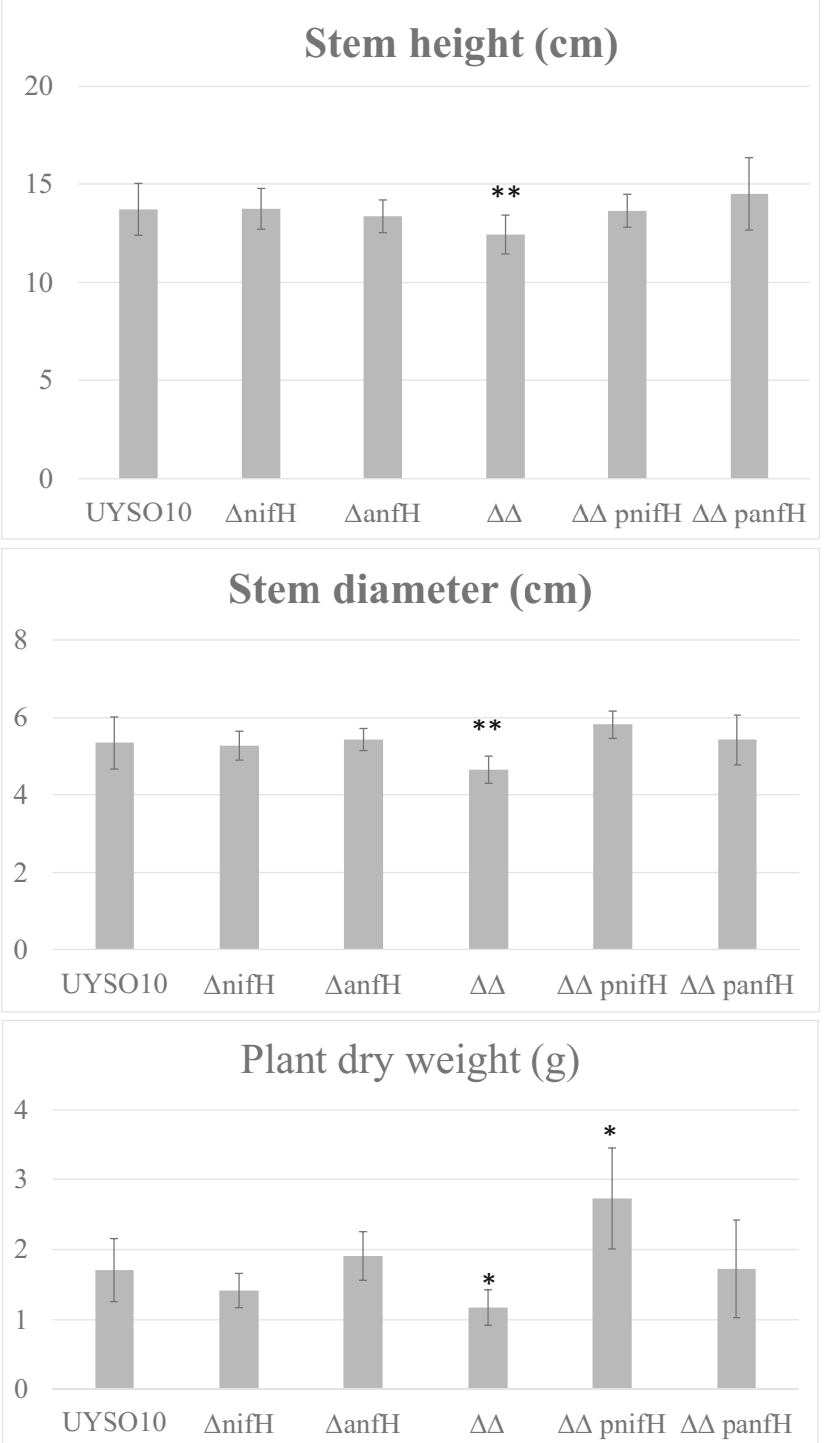

Fig. 3 Effects of inoculation with Kosakonia sp. UYSO10 and nitrogenase mutants on the growth of micropropagated sugarcane cv. LCP 85384 under growth chamber conditions. Treatments with an asterisk are significantly different compared with the wild-type strain at $* * p<0.05, * * * p<0.01$

\section{FeMo-nitrogenase and Fe-nitrogenase are present and active in Kosakonia sp. UYSO10}

Analyses of the Kosakonia sp. UYSO10 genome revealed that this strain has two nitrogenase gene clusters (nif and anf) that encode FeMo and Fe-nitrogenases. To evaluate its role in the observer sugarcane growth promotion, simple and double mutants were constructed and characterized in vitro and in vivo. ARA assays detected nitrogenase activity in every strain evaluated, but not in the double mutant $\Delta$ nifH- $\Delta a n f H$, for every experimental condition. These results clearly indicate that only when both nitrogenase structural genes are deleted, then strain UYSO10 is unable to carry out the BNF process. This result was also reported for the strain Rhodopseudomonas 
palustrus, a diazotrophic bacterium that contains three types of nitrogenases (Oda et al. 2005).

Recently, it was reported that the nitrogenase mutants $\Delta$ iff $H$ and $\Delta a n f H \Delta$ iff $H$ in the plant-associated strain K. radicincitans DSM $16656^{\mathrm{T}}$ were impaired in their ability to fix nitrogen (Ekandjo et al. 2018). The strain DSM16656 ${ }^{\mathrm{T}}$ has $98.91 \%$ genome similarity to the UYSO10 strain, and both strains have exactly the same nitrogenase nif and anf operon arrangement with almost $100 \%$ aa identity sequences. However, our results showed that both nitrogenases were active under the conditions analyzed, and these differences observed are likely to be related to the growth conditions and the methodology used to determine the BNF, or to the differences observed in the anfH gene sequence. In this sense, the phylogenetic tree based on the amino acid sequence of the AnfH protein showed that strain UYSO10 form a cluster with several Kosakonia strains, while the strain DSM $16656^{\mathrm{T}}$ is located in a separated branch (Table S1 and Fig. S2). Nevertheless, the nitrogenase activity of strain UYSO10 was not significantly affected by the presence or absence of Mo, as was reported for strain DSM16656 ${ }^{\mathrm{T}}$ (Ekandjo et al. 2018) and other diazotrophic strains such as $R$. palustris and Rhodospirillum rubrum (Lehman and Roberts 1991; Oda et al. 2005). This is not the case for the strains $A$. vinelandii and $R$. capsulatus, where a Mo concentration of $1 \mu \mathrm{M}$ or $10 \mathrm{nM}$ inhibits the expression of the alternative nitrogenases (Joerger et al. 1990; Schneider et al. 1991), suggesting a diverse regulation mechanism process. More experiments are required to elucidate the factors involved in the regulation of the expression and activity of both nitrogenases in strain UYSO10.

\section{The BNF process is involved in the sugarcane growth promotion by Kosakonia sp. UYSO10}

Kosakonia sp. UYSO10 inoculation into micropropagated sugarcane clearly showed that the BNF is partially involved in the plant growth promotion of cv. LCP85384. In addition, the inoculation of sugarcane plants with the knockout mutants for the nifH or anfH genes did not show a negative effect on the plant growth promotion, which means that both nitrogenases are active for the conditions tested.

The Kosakonia genus has been recently defined from a group of strains that were previously classified as Enterobacter (Brady et al. 2013). As mentioned, some of these strains have been reported to be plant-associated and to be plant-growth promoters (Kämpfer et al. 2005; Witzel et al. 2012; Brock et al. 2013; Bergottini et al. 2015). In particular, the strains Kosakonia sp. NN145S and NN143E were reported to be able to promote the growth of sugarcane plants and that the BNF was one of the mechanisms involved (Lin et al. 2012). In addition, strain Kosakonia sp. R4-368, isolated from Jatropa plants, was able to reduce acetylene and promote the growth of its plant host (Madhaiyan et al. 2013). A bioinformatic analysis of strain R4-368 genome only showed the presence of the nif regulon, and knockout mutants in the $n i f \mathrm{H}$, nif $\mathrm{D}$, and nifK genes lost their nitrogenase activity and their ability to promote plant growth (Madhaiyan et al. 2013). Alternatively, strains $K$. radicincitans DSM $16656^{\mathrm{T}}$ and UMEnt01/12, Kosakonia sp. NN145S and NN143E, $K$. oryzae Ola51T and YD4 have been shown to produce FeMo- and Fe-nitrogenases (Lin et al. 2012; Ekandjo et al. 2018; Li et al. 2017). Nevertheless, the role of the different nitrogenases in the PGP of their host is unknown for these strains.

In this study, we demonstrate the cultivar-specific PGP effects of the diazotroph endophytic strain Kosakonia sp. UYSO10 on setts of one of the most common sugarcane cultivars grown in Uruguay. In addition, we demonstrate that both nitrogenases present in strain UYSO10 are functional and active in the conditions tested and that the $\mathrm{Fe}$ nitrogenase is not regulated by the Mo levels in the growth media. Additionally, the plant growth promotion assays demonstrated that the BNF is involved in the plant growth promotion of sugarcane plants by Kosakonia sp. UYS010. All of these results stress the potential of the strain Kosakonia sp. UYSO10 to serve as a model system to study plant growth promotion.

Funding This work was supported by grants from the Uruguayan Fund for the Promotion of Agricultural Technology (Fondo de Promoción de Tecnología Agropecuaria FPTA-275 and 331-INIA), the Uruguayan Program for the Development of the Basic Sciences (Programa de Desarrollo de las Ciencias Básicas-PEDECIBA), the Posgrade Academic Commission-UdelaR (Comisión Académica de Posgrado), and the Uruguayan National Agency for Innovation and Research (Agencia Nacional de Innovación e Investigación-ANII). The authors are very grateful to Ing. Agr. Fernando Hackembruch from the Agriculture Department of the Alcoholes Uruguay S.A.

\section{Compliance with ethical standards}

Conflict of interest The authors declare that they have no conflict of interest.

Research involving human participants and/or animals N/A.

Informed consent N/A.

\section{References}

Adesemoye AO, Kloepper JW (2009) Plant-microbes interactions in enhanced fertilizer-use efficiency. Appl Microbiol Biotechnol 85:1-12

Beneduzi A, Moreira F, Costa PB, Vargas LK, Lisboa BB, Favreto R, Baldani JI, Passaglia LMP (2013) Diversity and plant growth promoting evaluation abilities of bacteria isolated from sugarcane cultivated in the south of Brazil. Appl Soil Ecol 63:94-104 
Bergottini VM, Filippidou S, Junier T, Johnson S, Chain PS, Otegui MB, Zapata PD, Junier P (2015) Genome sequence of Kosakonia radicincitans strain $\mathrm{YD} 4$, a plant growth-promoting rhizobacterium isolated from yerba mate (Ilex paraguariensis St Hill). Genome Announc 3:e00239-e00215

Bertalan M, Albano R, de Pádua V, Rouws L, Rojas C, Hemerly A, Teixeira K, Schwab S, Araujo J, Oliveira A, França L, Magalhães V, Alquéres S, Cardoso A, Almeida W, Loureiro M, Nogueira E, Cidade D, Oliveira D, Simão T, Macedo J, Valadão A, Dreschsel M, Freitas F, Vidal M, Guedes H, Rodrigues E, Meneses C, Brioso P, Pozzer L, Figueiredo D, Montano H, Junior J, de Souza Filho G, Martin Quintana Flores V, Ferreira B, Branco A, Gonzalez P, Guillobel H, Lemos M, Seibel L, Macedo J, Alves-Ferreira M, Sachetto-Martins G, Coelho A, Santos E, Amaral G, Neves A, Pacheco A, Carvalho D, Lery L, Bisch P, Rössle SC, Ürményi T, Rael Pereira A, Silva R, Rondinelli E, von Krüger W, Martins O, Baldani J, Ferreira PC (2009) Complete genome sequence of the sugarcane nitrogen-fixing endophyte Gluconacetobacter diazotrophicus Pal5. BMC Genomics 10:450

Brady C, Cleenwerck I, Venter S, Coutinho T, De Vos P (2013) Taxonomic evaluation of the genus Enterobacter based on multilocus sequence analysis (MLSA): proposal to reclassify E. nimipressuralis and E. amnigenus into Lelliottia gen. nov. as Lelliottia nimipressuralis comb. nov. and Lelliottia amnigena comb. nov. Syst Appl Microbiol 36:309-319

Brock AK, Berger B, Mewis I, Ruppel S (2013) Impact of the PGPB Enterobacter radicincitans DSM 16656 on growth, glucosinolate profile, and immune responses of Arabidopsis thaliana. Microb Ecol 65:661-670

Carvalho TLG, Ferreira PCG, Hemerly AS (2011) Sugarcane genetic controls involved in the association with beneficial endophytic nitrogen fixing bacteria. Trop Plant Biol 4:31-41

Compant S, Clément C, Sessitsch A (2010) Plant growth-promoting bacteria in the rhizo- and endosphere of plants: their role, colonization, mechanisms involved and prospects for utilization. Soil Biol Biochem 42:669-678

da Silva M, de Souza AC, de Oliveira PJ, Xavier GR, Rumjanek NG, de Barros Soares LH, Reis VM (2012) Survival of endophytic bacteria in polymer-based inoculants and efficiency of their application to sugarcane. Plant Soil 356:231-243

Edgar RC (2004) MUSCLE: multiple sequence alignment with high accuracy and high throughput. Nucleic Acids Res 32:1792-1797

Ekandjo LK, Ruppel S, Remus R, Witzel K, Patz S, Becker Y (2018) Site-directed mutagenesis to deactivate two nitrogenase isozymes of Kosakonia radicincitans DSM16656 ${ }^{\mathrm{T}}$. Can J Microbiol 64:97-106

Figurski DH, Helinski DR (1979) Replication of an origin-containing derivative of plasmid RK2 dependent on a plasmid function provided in trans. Proc Natl Acad Sci U S A 76:1648-1652

Fischer D, Pfitzner B, Schmid M, Simões-Araújo JL, Reis VM, Pereira W, Ormeño-Orrillo E, Hai B, Hartmann A (2012) Molecular characterization of the diazotrophic bacterial community in uninoculated and inoculated field-grown sugarcane (Saccharum sp.). Plant Soil 356:83-99

Fogliata F (1995) Agronomía de la caña de azúcar. In: El graduado (Ed.) Tecnología, costos y producción. Tucumán, Argentina, pp 1-10

Friesen ML (2013) Microbially mediated plant functional traits. In: de Bruijn FJ (ed) Molecular microbial ecology of the rhizosphere, 1st edn. John Wiley \& Sons, New Jersey, pp 87-102

Govindarajan M, Balandreau J, Kwon SW, Weon H-Y, Lakshminarasimhan C (2008) Effects of the inoculation of Burkholderia vietnamensis and related endophytic diazotrophic bacteria on grain yield of rice. Microb Ecol 55:21-37

Hallmann J, Quadt-Hallmann A, Mahaffee WF, Kloepper J (1997) Bacterial endophytes in agricultural crops. Can J Microbiol 43: 895-914
Hanahan D (1983) Studies on transformation of Escherichia coli with plasmids. J Mol Biol 166(4):557-580

Hardoim PR, van Overbeek LS, Berg G, Pirttilä AM, Compant S, Campisano A, Döring M, Sessitsch A (2015) The hidden world within plants: ecological and evolutionary considerations for defining functioning of microbial endophytes. Microbiol Mol Biol Rev 79:293-320

Hardy RW, Holsten RD, Jackson EK, Burns RC (1968) The acetyleneethylene assay for $\mathrm{N}_{2}$ fixation: laboratory and field evaluation. Plant Physiol 43:1185-1207

Horton RM, Hunt HD, Ho SN, Pullen JK, Pease LR (1989) Engineering hybrid genes without the use of restriction enzymes: gene splicing by overlap extension. Gene 77:61-68

InfoStat (2008). Grupo InfoStat, FCA, Universidad Nacional de Cordóba, Argentina

James EK (2000) Nitrogen fixation in endophytic and associative symbiosis. F Crop Res 65:197-209

Joerger RD, Loveless TM, Pau RN, Mitchenall LA, Simon BH, Bishop PE (1990) Nucleotide sequences and mutational analysis of the structural genes for nitrogenase 2 of Azotobacter vinelandii. $\mathrm{J}$ Bacteriol 172:3400-3408

Kämpfer P, Ruppel S, Remus R (2005) Enterobacter radicincitans sp. nov., a plant growth promoting species of the family Enterobacteriaceae. Syst Appl Microbiol 28:213-221

Kumar S, Stecher G, Tamura K (2016) MEGA7: molecular evolutionary genetics analysis version 7.0 for bigger datasets. Mol Biol Evol 33: 1870-1874

Lehman LJ, Roberts GP (1991) Identification of an alternative nitrogenase system in Rhodospirillum rubrum. J Bacteriol 173:5705-5711

Li Y, Li S, Chen M, Peng G, Tan Z, An Q (2017) Complete genome sequence of Kosakonia oryzae type strain Ola 51T. Stand Genomic Sci 12:8-11

Lin L, Li Z, Hu C, Zhang X, Chang S, Yang L, Li Y, An Q (2012) Plant growth-promoting nitrogen-fixing Enterobacteria are in association with sugarcane plants growing in Guangxi, China. Microbes Environ 27:391-398

Madhaiyan M, Peng N, Te NS, Hsin IC, Lin C, Lin F, Reddy C, Yan H, Ji L (2013) Improvement of plant growth and seed yield in Jatropha curcas by a novel nitrogen-fixing root associated Enterobacter species. Biotechnol Biofuels 6:140

Martínez-García E, de Lorenzo V (2011) Engineering multiple genomic deletions in gram-negative bacteria: analysis of the multi-resistant antibiotic profile of Pseudomonas putida KT2440. Environ Microbiol 13:2702-2716

Masclaux-Daubresse C, Daniel-Vedele F, Dechorgnat J, Chardon F, Gaufichon L, Suzuki A (2010) Nitrogen uptake, assimilation and remobilization in plants: challenges for sustainable and productive agriculture. Ann Bot 105:1141-1157

Mei C, Flinn BS (2010) The use of beneficial microbial endophytes for plant biomass and stress tolerance improvement. Recent Pat Biotechnol 4:81-95

Mirza BS, Rodrigues JL (2012) Development of a direct isolation procedure for free-living diazotrophs under controlled hypoxic conditions. Appl Environ Microbiol 78:5542-5549

Oda Y, Samanta SK, Rey FE, Wu L, Liu X, Yan T, Zhou J, Harwood CS (2005) Functional genomic analysis of three nitrogenase isozymes in the photosynthetic bacterium Rhodopseudomonas palustris. $\mathrm{J}$ Bacteriol 187:7784-7794

Oliveira ALM, de Canuto EL, Urquiaga S, Reis VM, Baldani JI (2006) Yield of micropropagated sugarcane varieties in different soil types following inoculation with diazotrophic bacteria. Plant Soil 284:2332

Oliveira ALM, Urquiaga S, Döbereiner J, Baldani JI (2002) The effect of inoculating endophytic $\mathrm{N}_{2}$-fixing bacteria on micropropagated sugarcane plants. Plant Soil 242:205-215 
Reis Junior F, Reis VM, Da Silva L, Dobereiner J (2000) Levantamento e quantificaçao de bactérias diazotróficas em diferentes genotipos de cana-de-açúcar (Saccharum spp.). Pesqui Agropecuária Bras 35: 985-994

Schneider K, Müller A, Schramm U, Klipp W (1991) Demonstration of a molybdenum- and vanadium-independent nitrogenase in a nifHDKdeletion mutant of Rhodobacter capsulatus. Eur J Biochem 195: 653-661

Schulz BJE, Boyle CJC (2006) What are endophytes? In: Schulz B, Boyle C, Sieber TN (eds) Microbial root endophytes. Springer, Berlin, pp 1-13

Sevilla M, Burris RH, Gunapala N, Kennedy C (2001) Comparison of benefit to sugarcane plant growth and ${ }^{15} \mathrm{~N}_{2}$ incorporation following inoculation of sterile plants with Acetobacter diazotrophicus wildtype and Nif mutant strains. Mol Plant-Microbe Interact 14:358366

Silva-Rocha R, Martínez-García E, Calles B, Chavarría M, ArceRodríguez A, de Las Heras A, Páez-Espino AD, DuranteRodríguez G, Kim J, Nikel PI, Platero R, de Lorenzo V (2013) The standard European vector architecture (SEVA): a coherent platform for the analysis and deployment of complex prokaryotic phenotypes. Nucleic Acids Res 41:666-675

Sinclair TR, Rufty TW (2012) Nitrogen and water resources commonly limit crop yield increases, not necessarily plant genetics. Glob Food Sec 1:94-98
Sullivan MJ, Petty NK, Beatson SA (2011) Easyfig: a genome comparison visualizer. Bioinformatics 27:1009-1010

Taulé C, Castillo A, Villar S, Olivares F, Battistoni F (2016) Endophytic colonization of sugarcane (Saccharum officinarum) by the novel diazotrophs Shinella sp. UYSO24 and Enterobacter sp. UYSO10. Plant Soil 403:403-418

Taulé C, Mareque C, Barlocco C, Hackembruch F, Reis VM, Sicardi M, Battistoni F (2012) The contribution of nitrogen fixation to sugarcane (Saccharum officinarum L.), and the identification and characterization of part of the associated diazotrophic bacterial community. Plant Soil 356:35-49

Thaweenut N, Hachisuka Y, Ando S, Yanagisawa S, Yoneyama T (2011) Two seasons study on nifH gene expression and nitrogen fixation by diazotrophic endophytes in sugarcane (Saccharum spp. hybrids): expression of nifH genes similar to those of rhizobia. Plant Soil 338:435-449

Witzel K, Gwinn-Giglio M, Nadendla S, Shefchek K, Ruppel S (2012) Genome sequence of Enterobacter radicincitans DSM16656 ${ }^{(\mathrm{T})}$, a plant growth-promoting endophyte. J Bacteriol 194:5469

Zhu B, Chen M, Lin L, Yang L, Li Y, An Q (2012) Genome sequence of Enterobacter SP. strain SP1, an endophytic nitrogen-fixing bacterium isolated from sugarcane. J Bacteriol 194:6963-6964

Publisher's note Springer Nature remains neutral with regard to jurisdictional claims in published maps and institutional affiliations. 